Published on Reviews in History (https://reviews.history.ac.uk)

\title{
The Shape of the State in Medieval Scotland, 1124-1290
}

Review Number: 2094

Publish date: Thursday, 20 April, 2017

Author: Alice Taylor

ISBN: 9780198749202

Date of Publication: 2016

Price: $£ 85.00$

Pages: 560pp.

Publisher: Oxford University Press

Publisher url: https://global.oup.com/academic/product/the-shape-of-the-state-in-medieval-scotland-1124-12909780198749202?cc=gb\&lang=en \&

Place of Publication: Oxford

Reviewer: Toby Salisbury

When it comes to Scotland, English historians are often still guilty of presuming that, before the Wars of Independence at least, the government of their northerly neighbour was unsophisticated and in desperate need of the help of English institutions in becoming an effective state. This sort of speculative thought is of course one of the more myopic pillars of English exceptionalism. Alice Taylor, lecturer in Medieval History at King's College London, offers the first full-length study of 12th- and 13th-century Scottish government as an intensive case study for the advancement of comparative approaches to the study of the development of European states.(1) The Shape of the State in Medieval Scotland shows that Scottish government in this period was more potent than previously thought, and, whilst external influence was of course a factor in the growth of bureaucratic government in Scotland, it was by no means the whole story. To a considerable degree, the constitution of the medieval Scottish state came about from organic, internal developments within Scotland itself that took root gradually.

The book is divided into two parts, each representing a distinct phase in the infancy of the Scottish state. This division results from what Taylor sees as the development of formal institutions of government being a much more gradual process than others have previously asserted. Such changes occurred later than the watermark reign of David I, a period in which many historians, most noticeably Geoffrey Barrow, have argued these institutions were created.(2) We should stop, Taylor argues, viewing the 12th and 13th centuries as a single, homogenous era. With this sentiment in mind, the first half of the book looks at noninstitutional power structures that crystallised in the 12th century. Piecemeal changes in this period, particularly in land-holding, ensured the importance of various local élites to the king in having his government exercised in the localities. It is only by understanding these non-institutionalised power relationships that we can fully appreciate the large role played by the same group of élites in the mechanisms of state seen in the following century. The second half of the book examines three spheres of government (royal office holding, the common law, and public finance), the internal workings of which are shown to be innately coloured by the developments in power relationships outlined in the first part of the book. One half of the book informs the other and vice versa. This reciprocal format works well, serving to effectively underline Taylor's thesis of gradual development. 
Scottish government in this period has often been assumed to have been weak, based on the existence of an aristocratic élite that supposedly held too much power in a private capacity, leaving royal government shackled and ineffective as a result. One of the primary aims of this book is to challenge this notion, which Taylor calls a 'fallacy' (p. 3). Instead, Taylor puts forward the idea that royal and aristocratic power were coterminous: kings and aristocrats relied on each other in a mutually beneficial arrangement and this was an essential element of many of the constitutions of medieval states. This theme is present throughout the book, but is examined most explicitly in the first chapter, which considers how kings of Scots exerted influence on their kingdom through their relationship with localised political society. Whereas previous generations of historians, most noticeably Alexander Grant, have seen the preponderance of mormair (the Scots equivalent of English earls) and toisig (thanes) in royal office-holding as resulting from a power struggle between royal and provincial authority, Taylor argues that we needn't view the situation in such conflicting terms. Instead, Taylor demonstrates that the king ultimately maintained power in the provinces through the gifting of land and appurtenant offices to local potentes who, by virtue of already being prominent in a given territory, were ideally suited to the responsibility of tasks such as raising the provincial army (in the case of mormaer, who enjoyed significant revenues from their roles in royal administration), or the running of the king's estates (in the case of toisig, who received a proportion of estate revenues for their service). In making use of men of local importance in this way, the king became connected to a provincial power grid, but it wasn't just the king who benefitted from the arrangement. Naturally, royal service was sought after by prominent men of the localities as a way of getting ahead, as well as consolidating the very position that made them attractive as administrators to the king in the first place. Royal power did not, therefore, come at the expense of aristocratic power.

The extraction of common burdens in Scotland is the subject of the second chapter, where we again see the key role played by the harmonious interplay between the king and an aristocratic powerbase in governance. Taylor emphasises that Scots kings were reasonably well-endowed with resources but, whilst their power was extended across the kingdom, it did not necessarily penetrate society much further than the local potentes discussed in chapter one. Great lords oversaw the levying of common services rather than there being a uniform apparatus, operated by agents of the crown, of the type one might expect of an administrative state. Scots kings lacked the administrative base from which to effectively extract services on their own. In an article of 2011, Taylor hinted that perhaps this was the result of a failure on the part of a king who could not break aristocratic holds over communal levies.(3) However, Taylor now revises this earlier inclination and notes instead that the key role played by aristocratic power in the levying of common obligations should be viewed as part of the same harmonious process outlined in chapter one. To a significant degree, the landgranting and subsequent territorialisation of aristocratic power was responsible for the king's ability to mobilise the resources of his realm: the powerful and enfranchised men of the provinces were most effective at extracting the realm's obligations on the king's behalf. The king's authority was further strengthened by his ability to grant exemptions from fiscally assessed burdens, not just through his ability to implement them in the first place.

Taylor outlines two major shifts in the writing of law and the maintenance of order within Scotland. The first saw the king gradually take on a greater role as a creator of law in its written form. Scots kings had always played a part in the making of law in their kingdom, but there were also judges (iudices), who are described in charters as being men of legal knowledge and who presided over cases in the 12th century, and who were also makers of law. Iudices worked over a wide regional area as well as at a local level and they were responsible for much of the realm's judicial business, but it is unclear exactly what degree of legal specialism they possessed. Taylor demonstrates how Scottish kings, particularly William the Lion, attempted to bring the creation of written law under their authority in royal assemblies. This led to a much-diminished role for the iudices, whose place in the judicial process became more restricted to localised law enforcement as the 12th century wore on and who seem to have faded completely from law-making assemblies by the early 13 th century.

The second major change to the law in this period saw the emergence of explicit methods of enforcement 
being incorporated into written law. By the mid-13th century, legal prescriptions regarding many types of procedure were fully situated within an institutional and jurisdictional structure they had not previously been a part of. General rules of practice were laid out in charters, as were rules for specific jurisdictions, such as magnate and royal courts. There was, Taylor argues, significant development in thinking on the role of aristocratic jurisdiction in the late 12th and early 13th centuries and this coincided with a growing administrative apparatus which starts to be evidenced in charters in the 1160s, but only appears in written law by 1230 . This is the result of charters representing changes to law: charters were created on a case-bycase basis, whereas written law represents the formal culmination of existing practices. Charter evidence shows that the growing presence of the king's interests in legal proceedings came before its formalisation in written law. Aristocratic, as well as royal courts were increasingly concerned with the king's rights, even over land that had been granted away. The king could expect to receive fines for a variety of forfeitures, such as infringements on private forest and warren rights. Taylor notes that a scenario in which the king received a fine from a third-party transgression against a lord's forest rights could be construed as a significant infringement on aristocratic rights (p. 154). It would be interesting to speculate, if the evidence permits, not just how Scottish kings profited from offences in private forests, but how forest law was administered across the varying jurisdictions under discussion in this book and whether or not this reinforces the picture of cooperative administration.

The first half of the book examines changes to the conception and relationship of royal and aristocratic power in the 12th century. The second half provides an in-depth examination of the development of the main bureaucratic institutions set alongside the changes outlined in the first half.

All three of the institutions under examination in chapter four - the shrievalty, and the offices of justiciar and chamberlain - experienced profound changes over the period 1170-1290. Of these institutions, only the justiciar has been the subject of a standalone study before.(4) Sheriffs and justices began to exercise jurisdictions over a fixed territorial area. The emergence of the sheriff as a uniform part of local government in turn enabled the itinerant work of both the justiciar and chamberlain. The sheriff soon became the unit of royal government in the localities. Taylor is quick to stress that the development of the shrieval court did not 'develop in a vacuum' (p. 264), arguing that there is an important distinction be made between the de facto position some sheriffs occupied before this period, and the official one they held in the legislation of Alexander II. The developments of these offices fundamentally altered and improved the way the Scottish state was administered. Once more, at the root of this development was the harmonious and symbiotic relationship between the king and the aristocracy. These changes could not have been made without the willing cooperation of powerful lords and the motivational forces of mutual self-interest. The official nature of these offices made them attractive to lords whose own power was legitimised by the royal association and royal government benefitted immensely from the increasingly localised position of these administrators.

The development of a common law, that is a law common to all, upheld by the king's courts throughout the realm, and distinct from both customary and canon law, is regularly seen as a cornerstone of state development. It is understandable then, that Taylor's largest chapter is dedicated to this theme. After a brief survey of the historiography of the Scottish common law, Taylor begins an examination of the legislation enacted under Alexander II, concluding that the four pieces of legislation produced in 1230 do not deserve their reputation as landmark moments in the history of Scottish common law. These acts protected aristocratic rights and privileged the same group in procedural terms. This should not be a surprise though, Taylor insists, in light of the power dynamics that emerged from the 12th century: aristocratic jurisdictions were vitally important to the administration of law and order. The written communiqués used to initiate cases of, for example, novel disseisin, known as brieves, have been discussed at length before.(5) Taylor argues convincingly that the focus in this area has been too narrow: too much attention has been given to pleadable brieves, leading to historians assuming the Scottish common law to be limited geographically and procedurally due to the separate jurisdictions of the great lordships. However, by looking at retourable as well as pleadable brieves, Taylor shows that brieves could and were used extensively in the courts of these great lordships. These courts, too, were expected to uphold the common law. These multiple jurisdictions were naturally incorporated into royal statutes as the king came to rely on them. They were central to 
common law development.

A paucity of source material has meant that no study on the accounting and revenue procedures of the medieval Scottish state has been forthcoming to date. Various accidents of history have led to the destruction of vital documents, foremost being the sinking of a ship under orders from Oliver Cromwell in 1660 to carry away records pilfered from Stirling Castle. For this task, Taylor is forced to rely on transcripts made by Thomas Haddington, first earl of Haddington (1563-1637), to draw her conclusions. Ever since their modern publication, these transcripts have been harvested by historians for financial data relating to the king's income. However, there has also been questions over the authority of this material since its publication. Taylor works hard to establish the validity of the Haddington transcripts but, as with all conclusions drawn from sources with such provenance, where validity is ultimately improvable, the spectre of the source's somewhat dubious authority will always loom. This being said, this chapter is exhaustive in its use of these documents and the author is able to make some interesting and convincing conclusions from an imperfect dataset. Scottish royal income was, as would be expected, much smaller than English royal income. Taylor also shows that the auditing of accounts that developed, at the latest, in the early 13th century, was not simply the result of following bureaucratic methods used in England. The relatively small scale of the Scottish state's financial operations meant that there was no apparent need for a separate and stationary Exchequer system like the English had at Westminster. Instead, what emerges again here is the importance of the sheriff in a system that was inherently localised, but one that was no less efficient for being so.

When questioning the extent to which the Scottish government was bureaucratised in this period, Taylor focuses on 'parchment and people': the examination of the documentary capacity of government and the extent to which royal officials were dependant on their roles within government to exist and prosper. The chapel emerged in 13th-century Scotland as a recordkeeping entity of great capacity. What's more, it was intensely audited and the processes of enrolment involved were complex and organic. When it comes to the people who populated royal office, the shrievalty is again the key to the state's operations. Their high status demonstrates their importance to the actions of central government, but is also indicative of the high degree to which locality and polity were co-dependant. Taylor stops short, therefore, of proclaiming a bureaucratic state, whilst also dismissing the Weberian label of the patrimonial state. These labels miss the development of complex institutions of government, the procedures of which borrowed their authority from the king.

Taylor concludes by drawing together the book's central themes and setting out the benefits of a comparative approach. First, it is stressed that presumptions of Anglicisation have gone too far. Studying the so-called 'peripheries' has too often assumed the domination of the 'core' - England, in this case. To make assumptions in this way is to overlook organic developments, particularly the subtle adaptation of borrowed institutions and practices. The lens of Anglicisation, Taylor notes, resembles the process of Europeanisation in its assumptions of cross-country influence. It represents one lens through which to view the history of the British Isles but it is one which does not help in the understanding of real changes internal to the countries that share borders with England. The study of single polities on their own terms is, therefore, the superior comparative approach.

Taylor hesitates to say whether there was, in fact, a Scottish state in the central Middle Ages, if only because of the habit of previous generations of historians who applied the criteria of a modern state as the sole signifiers for the existence of all states. By 1290, Scotland could claim to cover both the main criteria of the modern state: a monopoly over violence and abstract governmental institutions. However, in this distinctly medieval arrangement, governmental and institutional structures were based on the intermingled powerbase of monarchic and aristocratic power. Scotland was symbolically centralised under the king and government was mediated throughout the kingdom by aristocratic power and royal institutions which developed in tandem. Aristocratic power was, therefore, state power.

Even with misgivings about the authority of certain sources (and this applies only to a very small section of the book), the conclusions drawn here are so convincing that they almost retroactively add to the estimation of their sources. It is important to note that even where the evidence available is limited, it is pushed to its 
limits without overegging its conclusions. Any other available criticisms of this volume, that it would have been interesting to read more on the role played by bishops, for example, are clearly the result of limits in time and words. As another referendum looms, this book comes at an opportune moment to act as a corrective to the co-opting of the medieval past. It is ambitious and thorough; it succeeds in its stated aims, and then some.

\section{Notes}

1. This aspect of Taylor's book is timely, following on from George Molyneaux's work on the formation of the Anglo-Saxon English kingdom, which advocates a similar approach to comparative history: G. Molyneaux, The Formation of the English Kingdom in the Tenth Century (Oxford, 2015).Back to (1)

2. See Barrow's 1977 Ford Lectures: G. Barrow, The Anglo-Norman Era in Scottish History (Oxford, 1980). Back to (2)

3. A. Taylor, 'Common burdens in the Regnum Scottorum: the evidence of charter diplomatic', in Reality Behind Charter Diplomatic in Anglo-Norman Britain, ed. D. Broun et al. (Glasgow, 2011), pp. 166-234.Back to (3)

4. The previous study is by G. W. S. Barrow, see: 'The justiciar', in his The Kingdom of Scots: Government, Church and Society from the Eleventh to the Fourteenth Century (2nd ed., Edinburgh, 2003), pp. 68-111. Back to (4)

5. D. Broun, 'The adoption of brieves in Scotland', in Charters and Charter Scholarship in Britain and Ireland, ed. M. Flanagan and J. Green (Basingstoke, 2005), pp. 164-83.Back to (5)

Alice Taylor responds: I am grateful to Toby Salisbury for his positive conclusion and broadly accurate summary of my book.

Source URL:https://reviews.history.ac.uk/review/2094

\section{Links}

[1] https://reviews.history.ac.uk/item/247707 